\title{
Three new species of cytheracean Ostracoda from the Coralline Crag at Orford, Suffolk
}

\author{
A.M.WOOD \\ Institute of Earth Studies, \\ University of Wales, \\ Aberystwyth, U.K. SY23 3DB
}

\author{
R.C.WHATLEY \\ Institute of Earth Studies, \\ University of Wales, \\ Aberystwyth, U.K. SY23 3DB
}

\author{
C.A. MAYBURY \\ Institute of Earth Studies, \\ University of Wales, \\ Aberystwyth, U.K. SY23 3DB
}

\author{
I.P. WILKINSON \\ British Geological Survey, \\ Keyworth, \\ Nottingham NG12 5GG
}

\begin{abstract}
Three new index species of Pliocene Ostracoda, Haplocytheridea robusta, Aurila sherborni and Cletocythereis jonesi are described from the Coralline Crag Fm. at Orford, Suffolk. J. Micropalaeontol., 11 (2), 211-220, December 1992.
\end{abstract}

\section{INTRODUCTION}

The examination of sediment from a British Geological Survey borehole, OSC1 (GR. TM 43265017 ), situated $1 \mathrm{~km}$ east of Orford in the county of Suffolk (Figs 1-2) revealed a $10 \mathrm{~m}$ section of unleached skeletal carbonate sands and silty sands of the Coralline Crag Formation (Charlesworth, 1835; Andrew \& West, 1977; Balson, 1990). The Coralline Crag Formation, in the area around Orford, uncomformably overlies the Eocene London Clay Formation and can be subdivided into two lithostratigraphical Units, A \& B (Balson, 1981). Its lateral equivalent can also be seen at Sutton Knoll (TM 304 440) (fig. $3)$, the type section of the Coralline Crag Formation.

The ostracods, from both Units A \& B, yield a diverse fauna of 98 species belonging to 36 genera; with clearMediterranean/ Moroccan affinities. The fauna is dominated by a number of index species: Aurila sherbornisp. nov.; Aurila strongyla Wouters, 1973; Cletocythereis jonesi sp. nov.; Cytheretta harmeri Wilkinson, 1980; Cytheretta Woodiana (Jones, 1857); Haplocytheridea pinguis (Jones, 1857); Haplocytheridea robusta sp. nov.; Muellerina laconusa (Jones, 1857); Pontocythere botellina (Jones, 1870); Schizocythere pliocenica Wilkinson, 1980 and Thaerocy there trachypora (Jones, 1857). These important biostratigraphical index species, for both the Coralline Crag Formation and "Waltonian" Red Crag Formation, are to be figured in the Neogene chapter of the Revised Stratigraphical Index of British Ostracoda, due to be published in 1993.

\section{SYSTEMATIC DESCRIPTIONS \\ Class Ostracoda Latreille, 1806 \\ Order Podocopida Muller, 1894 \\ Suborder Podocopina Sars, 1866 \\ Superfamily Cytheracea Baird, 1850 \\ Family Cytherideidae Sars, 1925 \\ Subfamily Cytherideinae Sars, 1925 \\ Genus Haplocytheridea Stephenson, 1936}

List of abbreviations: ALV-F = Adult left valve, female. $\mathrm{ARV}-\mathrm{M}=$ Adult right valve, male. $\mathrm{ACp}=$ Adult carapace, A- $n=$ juvenile stage.
Discussion. The authors are of the opinion that Sarsicytheridea Athersuch (1982) is a junior synonym of Haplocytheridea. Both genera have a holomerodont hinge and differ solely in details of shape and vestibulium, which we consider to be of specific rather than generic degree.

Type Species. Cytheridea montgomeryensis Howe \& Chambers, 1935

\section{Haplocytheridea robusta $\mathrm{sp}$. nov.}

(Pl.1, figs 1-9)

1857 Cythere (Cytheridea) pinguis Jones: 43, pl.2, fig. 4a., (non: pl.2, fig. $4 \mathrm{~d}=$ Cytheretta harmeri Wilkinson 1980; pl.2, figs $4 b-c, e-f=C$. pinguis Jones, 1857).1980 Haplocytheridea pinguis (Jones); Wilkinson: pl.1, fig. 5.

Derivation of name. Latin, with reference to the strong and robust nature of the carapace.

Diagnosis. Strongly calcified species of Haplocytheridea, length to height ratio is lower than the norm for the genus. RV subtriangular with arched dorsal margin, LV sub-quadrate with weakly developed anterior denticulation. Coarse, scattered puncta developed in adults.

Type locality and Horizon. Coralline Crag Fm., OSC 1 borehole, sample horizon OR7a, Orford.

Material. Four adults, 32 juveniles from the present material. Numerous other specimens in various collections. Type specimens are deposited in the collections of the British Geological Survey (B.G.S.).

Dimensions of types (mm).

Holotype ALV-M

Paratype ARV-M

Paratype ALV-F

Paratype A-1LV

Paratype A-1RV

Paratype A-1Cp

Site
MPK 9272 OSC1/OR7a
MPK 9273 OSC1/OR7a
MPK 9274 OSC1/OR15
MPK 9275 OSC1/OR12
MPK 9276 OSC1/OR12
MPK 9277 OSC1/OR7a

$\begin{array}{cc}\text { Length } & \text { Height } \\ 1.1 & 0.70 \\ 1.11 & 0.65 \\ 1.04 & 0.68 \\ 0.91 & 0.63 \\ 0.93 & 0.53 \\ 0.94 & 0.54\end{array}$

Distribution. Pliocene; Coralline Crag, "Waltonian" Red Crag, East Anglia, England. FB zone (Doppert et al., 1979; Doppert, 1980) Oosterhout Fm, Holland. Redonian (late Pliocene); SaintJean-la Poterie, France.

Description. Large, thick-shelled. Dimorphism present but not pronounced. LV sub-quadrate in lateral view, anterior margin obliquely rounded and frilled with stunted marginal 

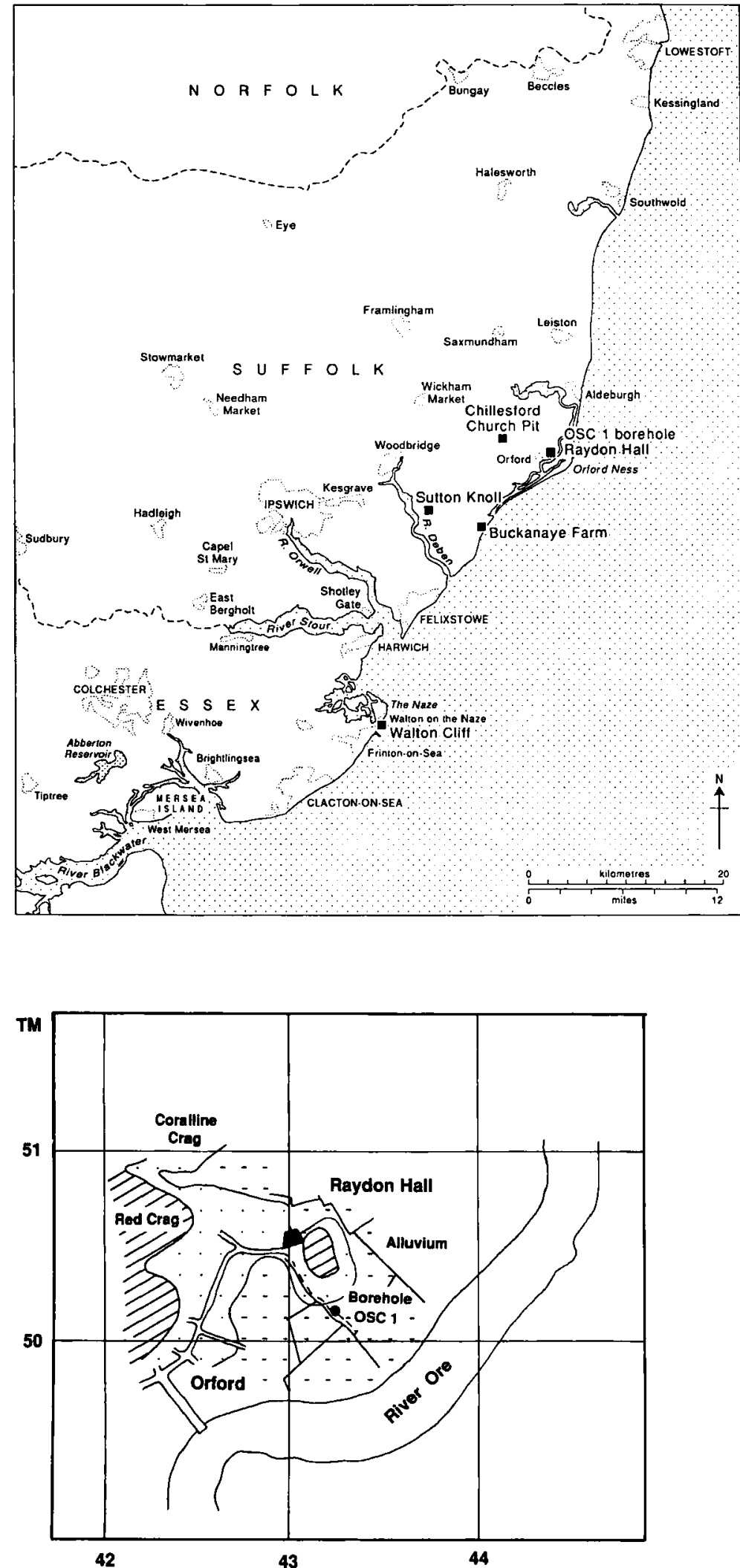

Fig. 2. Location of B.G.S. borehole OSC1, south-east of Raydon Hall (Adapted after Andrew \& West, 1977)
Fig. 1. Regional locality of the Orford borehole and other Pliocene sites presently under investigation

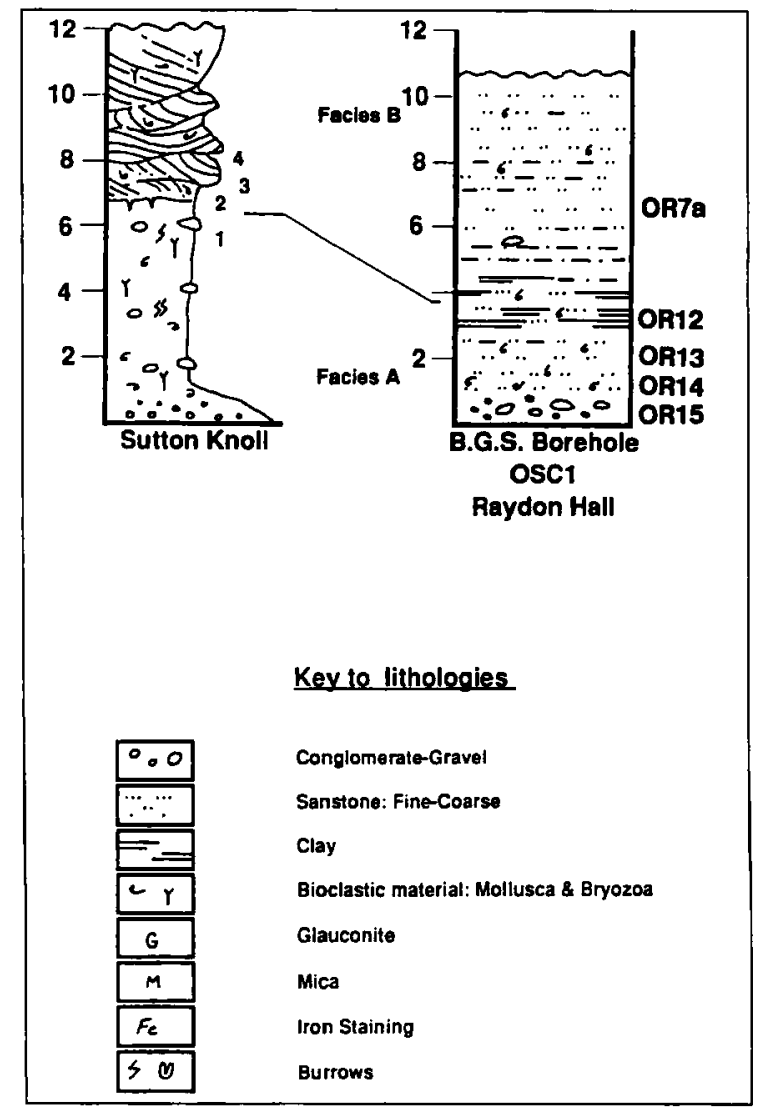

Fig. 3. Lithostratigraphy of borehole OSC1 and the type section for the Coralline Crag at Sutton Knoll 


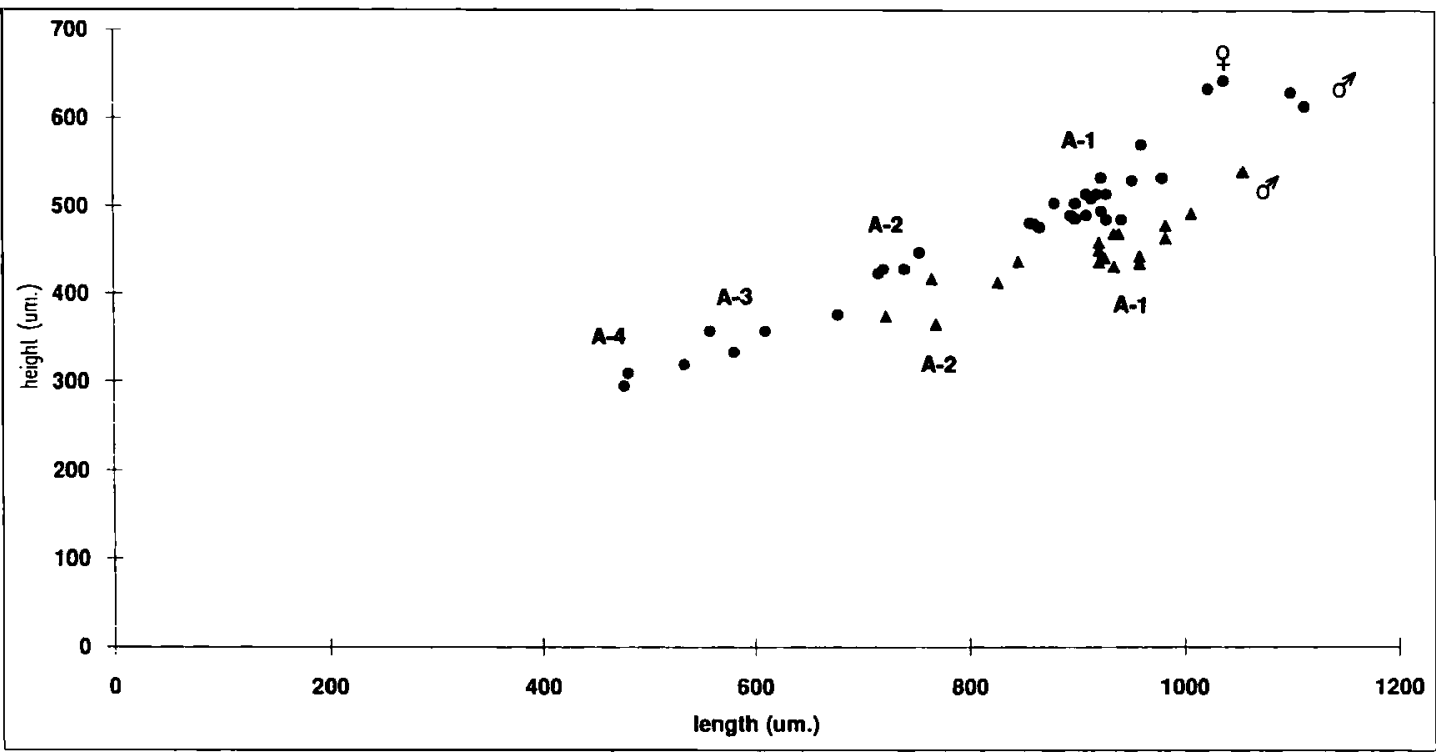

Fig. 4. Comparison in the size distribution of adults and juveniles of both Haplocytheridea robusta sp. nov. (O) and H. pinguis (Jones, 1857) (A).

denticles, posterior rounded; dorsal and ventral margins weakly convex to straight, sub-parallel. Extremities of end margins below mid height. RV sub-triangular in lateral view, anterior obliquely rounded, extremity below mid height; posterior narrowly rounded, extremity just sub-ventral; ventral margin sinuous, with slight oral concavity; dorsum convex. Cardinal angles weakly developed. Greatest height at anterior cardinal angle; greatest length mid-way between mid-height and ventral margin; greatest width anterior of mid point. $\mathrm{LV}>\mathrm{RV}$; overlapping around almost the entire periphery. Surface covered with deep widely scattered puncta. Inner lamella broad; anteriorly and posteriorly vestibulate; prominent selvage; marginal pore canals moderately numerous, straight/sinuous, rarely inflated medianly; 15 anterior, 7 orally, 14 posterior. Hinge holomerodont; 7 teeth in the anterior terminal element and 5 teeth in the posterior terminal element of both valves; toothlets of both the posterior and anterior elements in the RV with bifid cusps connected by a crenulated median bar; corresponding sockets in LV. Vertical row of four adductor muscle scars, with fulcral point anterior to the most dorsal; two frontal muscle scars, lower " $V$ " shaped; two mandibular scars: large elongate scar situated anteroventrally of the lowest adductor scar; smaller lobate scar situated ventrally of the adductors. Four dorsal scars forming a parallelogram dorsal of the adductors. Juveniles sub-trapezoidal in lateral view, weakly pitted with weakly developed anteroventral lips on both valves.

Dimensions (mm), (see Fig. 4)

$\begin{array}{lccccc} & \text { Size } & \text { Length } & \text { Height } & \text { Nos } & \text { L:H ratio } \\ \text { Female } & \text { Range } & 1.04-1.02 & 0.64-0.63 & 2 & 1.62: 1 \\ & \text { Mean } & 1.03 & 0.635 & & \\ \text { Male } & \text { R. } & 1.11-1.1 & 0.63-0.61 & 2 & 1.78: 1 \\ & \text { M. } & 1.1 & 0.62 & & \\ \text { A-1 } & \text { R. } & 0.98-0.86 & 0.57-0.48 & 20 & 1.81: 1 \\ & \text { M. } & 0.91 & 0.5 & & \\ \text { A-2 } & \text { R. } & 0.75-0.68 & 0.44-0.38 & 5 & 1.71: 1 \\ & \text { M. } & 0.72 & 0.42 & & \\ \text { A-3 } & \text { R. } & 0.61-0.52 & 0.36-0.32 & 4 & 1.67: 1 \\ & \text { M. } & 0.57 & 0.34 & & \end{array}$

Remarks. This species differs from Haplocytheridea pinguis (Jones, 1857) (pl.1, figs 10-11), in its markedly lower L:H ratio, greater robustness and the outline of the left (subquadrate) and right (subtriangular) valves. Juveniles of $H$. robusta are commonly mistaken for H.pinguis. However, the latter are markedly less high and have well developed puncta at least to the A-4 stage. The authors have seen the type material of Jones in the British Museum (Natural History) on the basis of which these comparisions are made.

Family Hemicytheridae Puri, 1953

Subfamily Aurilinae Puri, 1953

Genus Aurila Pokorny, 1955

Type species. Cythere convexa Baird, 1850

Aurila sherborni sp. nov.

(Pl.2, figs 1-10)

Derivation of name. In honour of C.Davies Sherborn in recognition of his contribution to the study of Pliocene Ostracoda of the East Anglian "Crags".

Diagnosis. A large, punctate species of Aurila with a well developed smooth, elongate sub-ovate eye tubercle and a swollen, "L"-shaped (in LV) opaque patch which surrounds the central muscle scars and continues dorsally in a band towards the hinge area (figs. 5a-5b).

Type locality and Horizon. Coralline Crag Fm., OSC1 borehole, sample horizon OR12, Orford.

Material. Seven adults, 15 juveniles in the present material together with specimens in other collections. Type specimens are deposited in the collection of the B.G.S, Keyworth. Dimension of types ( $\mathrm{mm})$.

$\begin{array}{llcc} & \text { Site } & \text { Length } & \text { Height } \\ \text { Holotype ARV-M } & \text { MPK 9288 OSC1/OR12 } & 0.89 & 0.50 \\ \text { Paratype LV A-1 } & \text { MPK 9289 OSC1/OR12 } & 0.81 & 0.56 \\ \text { Paratype ARV-F } & \text { MPK 9290 OSC1/OR7a } & 0.90 & 0.56 \\ \text { Paratype ALV-F } & \text { MPK 9291 OSC1/OR7a } & 0.91 & 0.58 \\ \text { Paratype ARV-F } & \text { MPK 9292 OSC1/OR7a } & 0.91 & 0.57 \\ \text { Paratype ALV-F } & \text { MPK 9293 OSC1/OR7a } & 0.84 & 0.55 \\ \text { Paratype ARV-F } & \text { MPK 9294 OSC1/OR12 } & 0.88 & 0.50 \\ \text { Paratype Cp A-1 } & \text { MPK 9295 OSC1/OR12 } & 0.83 & 0.52 \\ \text { Paratype LV A-2 } & \text { MPK 9296 OSC1/OR12 } & 0.71 & 0.42\end{array}$


Distribution. Pliocene; Coralline Crag and "Waltonian" Red Crag, East Anglia and St.Erth, Cornwall, England. Redonian (late Pliocene); Apigne (Gite d'Apigne, Borehole II), France.

Description. Large, subovate-subcircular. Strongly dimorphic, males being much more elongate than females. Anterior margin rounded, extremity at or just below mid-height, antero-dorsally convex in LV, oblique to slightly concave in RV. Dorsal margin of RV arcuate, with straight posterodorsal slope; posterior margin subovate in RV, subrounded in LV with apex below midheight, concave postero-dorsal and convex postero-ventral slopes. Dorsal margin strongly convex in LV, gently in female RV, almost straight in male RV. Caudal process convex with singular marginal denticle. Ventral margin with oral invagination strongly developed in RV. Greatest height at mid-length in LV and at the anterior cardinal angle of RV; greatest width median. Anterior cardinal angle indistinct, posterior cardinal angle prominent in RV, less so in LV. LV > RV. Lateral surface punctate with almost smooth flattened ventral and anterior rims. A number of very delicate symmetrical "wave-like" ridges parallel the anterior and posterior margins. Sensillum pores, numerous, normal and sieve type. Well developed smooth, elongate sub-ovate eye tubercle. Swollen, "L"-shaped opaque patch (in the LV), which surrounds the central muscle scar area and continues postero-dorsally in a bulbous band towards the hinge. Juveniles finely punctate. Dorsal margin less convex than the adults; with prominent posterodorsal slope. Posteroventral denticle present in both the A-1 and A-2 stages.

\begin{tabular}{|c|c|c|c|c|c|}
\hline \multicolumn{6}{|c|}{ Dimensions (mm) (see fig.6) } \\
\hline Size & Length & Height & Nos & \multicolumn{2}{|c|}{$\mathrm{L}: \mathrm{H}$ ratio } \\
\hline \multirow[t]{2}{*}{ Female } & Range & $0.91-0.83$ & $0.56-0.50$ & 6 & $1.86: 1$ \\
\hline & Mean & 0.89 & 0.54 & & \\
\hline Male & R. & 0.89 & 0.48 & 1 & $1.66: 1$ \\
\hline \multirow[t]{2}{*}{ A-1 } & $\mathbf{R}$ & $0.87-0.77$ & $0.59-0.44$ & 6 & $1.61: 1$ \\
\hline & M. & 0.81 & 0.50 & & \\
\hline \multirow[t]{2}{*}{ A-2 } & $\mathrm{R}$. & $0.72-0.67$ & $0.42-0.38$ & 5 & $1.65: 1$ \\
\hline & M. & 0.70 & 0.41 & & \\
\hline \multirow[t]{2}{*}{$A-3$} & $\mathbf{R}$. & $0.61-0.59$ & $0.40-0.38$ & 3 & $1.51: 1$ \\
\hline & M. & 0.60 & 0.39 & & \\
\hline A-4 & M. & 0.47 & 0.31 & 1 & $1.51: 1$ \\
\hline
\end{tabular}

Remarks. The atypical outline of $A$. sherborni $s p$. nov. distinguishes this aurilid from others, such as $A$. strongyla Wouters, 1973; which also occurs in the Pliocene of the Southern North Sea. The material described by Maybury 1985 (MS) from the
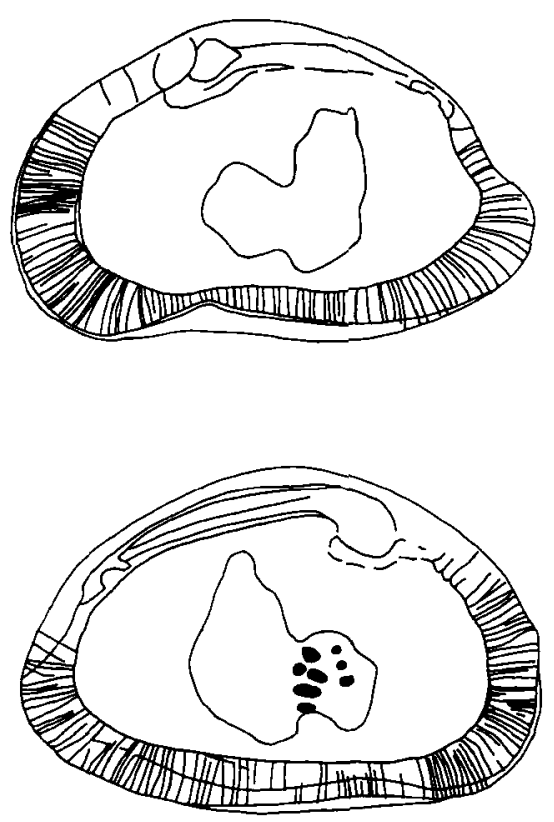

\section{A}

Fig. 5 a. Aurila sherborni; LV-F, paratype MPK 9293, OSC1/OR7a, as seen in transmitted light b. LV A-1. paratype MPK 9289, OSC1/ OR7a, seen in transmitted light. Scale $A=100 u m$

Pliocene of St.Erth, Cornwall and Apigne, France is somewhat smaller than that from the North Sea. From the type species, $A$. convexa (Baird), the present species differs in being substantially larger, possessing a well developed elongate eye tubercle and having a swollen " $\mathrm{L}$ "-shaped opaque patch.

Family Trachyleberidae Sylvester-Bradley, 1948

Subfamily Trachyleberidinae Sylvester-Bardley, 1948

Genus Cletocythereis Swain, 1963

Type species. Cythere rastomarginata Brady, 1880

Cletocythereis jonesi sp. nov.

(Pl.2, figs 11-15; Pl.3, figs 1-12)

1857 Cythere macropora Bosquet; Jones: 35 , pl.3, figs 9a-9e. (non pl.3, fig. 9e = Cythere lacunosa Jones, 1857).

1879 Cythere macropora Bosquet: Jones: 158.

1887 Cythereis hoernesi (Speyer); Jones \& Sherborn: 454. 1889 Cythereis hoernesi (Speyer); Jones \& Sherborn: 32, pl.1, fig. 7.

1980 Hermanites haidingeri haidingeri (Reuss); Wilkinson: pl.2, fig. 11.

Explanation of Plate 1

Figs 1-9. Haplocytheridea robusta sp. nov.: fig. 1, Holotype MPK 9272 LV-M, ext. lat. (x46); fig 2, Paratype MPK 9273 RV-M, ext. lat (x46); fig. 3, Holotype MPK 9272, int. dorsal inclined (x47); fig. 4, Paratype MPK 9273, int. dorsal inclined (x46); fig. 5a, Paratype MPK 9273, int. lat. (x46); fig. 5b, Paratype MPK 9273, detail of hinge (x123); fig. 5c, Paratype MPK 9273, detail of central muscle scars (x110); Fig. 6a, Holotype MPK 9272, int. lat. (x47); fig. 6b, Holotype MPK 9272, detail of hinge (x105); fig. 6c, Holotype MPK 9272, detail of central muscle scars (x103); fig. 7, Paratype MPK 9275 LV A-1, ext. lat. (x46); fig. 8, Paratype MPK 9277 Cp A-1, ext ventral (x33); fig. 9, Paratype MPK 9276 RV A-1, ext. lat (x46).

Figs 10-11. Haplocytheridea pinguis (Jones, 1857): fig. 10, Holotype I807 RV-M, int. lat. (x50); fig. 11, Holotype I807, ext. lat. (x50). 

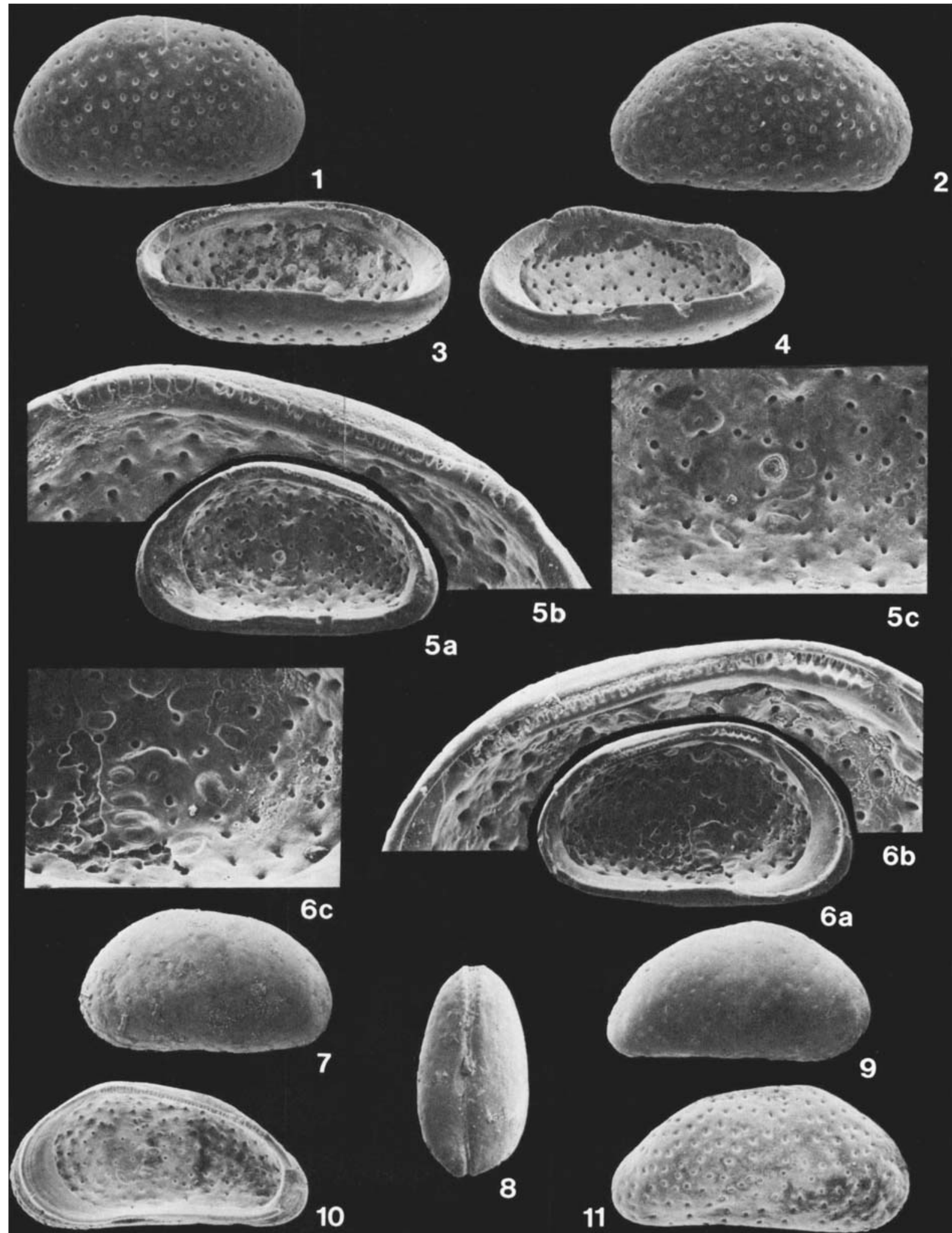

9

8

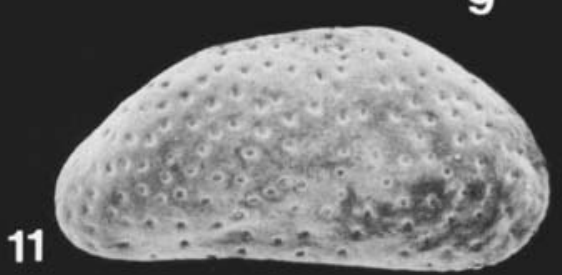




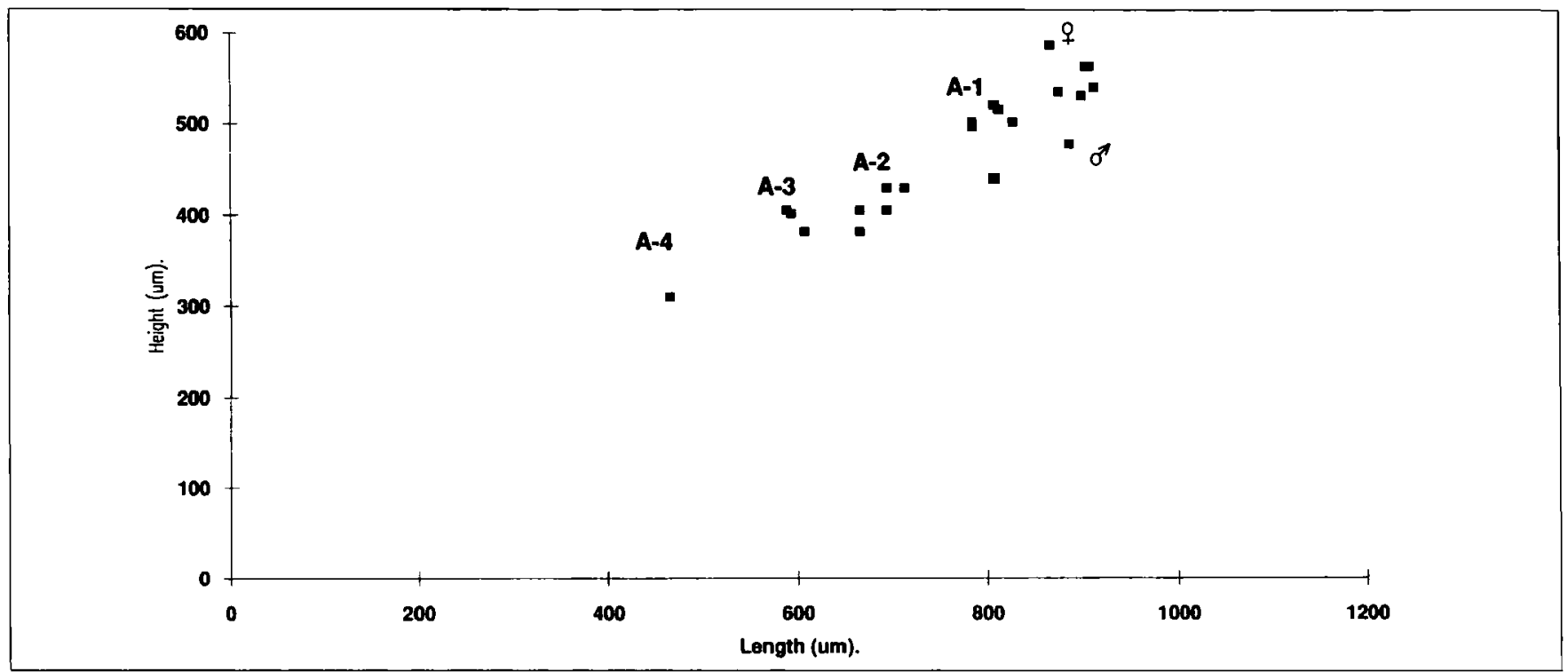

Fig. 6. Size distribution of adults and juveniles of Aurila sherborni sp. nov.

Derivation of name. In honour of Prof. T. Rupert Jones in recognition of his contribution to the study of Ostracoda. Diagnosis. A large sub-rectagular species of Cletocythereis, surface strongly reticulated with large, marginally linked, sellate fossae. Anterior marginal rim recticulate with a series of narrow transverse, elongate, sellate fossae. There are two prominent dorsal ridges and a prominent sub-alar ridgeventrolaterally which terminates in a complex "loop" posteroventrally. Characteristic antero-dorsal expansion of the selvage, forming a small rim-tooth in the LV anterior of the anterior terminal socket (McKenzie, 1967; Malz, 1980).

Type locality and Horizon. Sutton Knoll, Suffolk. Material. Fifteen adults, 25 juveniles from the present material. Numerous other specimens in various collections. The holotype is deposited in the British Museum (Natural History); the Paratypes in the B.G.S., Keyworth.

\section{Dimension of types (mm).}

$\begin{array}{lllcc}\text { Holotype ACP-M } & \text { OS 13949 } & \text { ?Sutton Knoll } & \text { Length } & \text { Height } \\ \text { Paratype ALV-F } & \text { MPK 9278 } & \text { OSC1/OR7a } & 1.07 & 0.55 \\ \text { Paratype ALV-M } & \text { MPK 9279 } & \text { OSC1/OR7a } & 1.02 & 0.57 \\ \text { Paratype ARV-M } & \text { MPK 9280 } & \text { OSC1/OR7a } & 1.09 & 0.53 \\ \text { Paratype ALV-M } & \text { MPK 9281 } & \text { OSC1/OR12 } & 1.10 & 0.58 \\ \text { Paratype ALV-F } & \text { MPK 9282 } & \text { OSC1/OR12 } & 1.00 & 0.58 \\ \text { Paratype A-1 } & \text { MPK 9283 } & \text { OSC1/OR12 } & 0.81 & 0.43 \\ \text { Paratype A-2 } & \text { MPK 9284 } & \text { OSC1/OR14 } & 0.62 & 0.34 \\ \text { Paratype A-1 } & \text { MPK 9285 } & \text { OSC1/OR12 } & 0.76 & 0.47 \\ \text { Paratype A-2 } & \text { MPK 9286 } & \text { OSC1/OR12 } & 0.62 & 0.38 \\ \text { Paratype ACp-F } & \text { MPK 9287 } & \text { OSC1/OR12 } & 1.09 & 0.62\end{array}$

Distribution. Upper Miocene; Duerne Sands, Belgium. Pliocene; Kattendijk Fm., Antwerp, Belgium (op. cit. Wouters, $1978 \mathrm{MS})$. Lower Pliocene; borehole $43 \mathrm{H} 63211.5-239 \mathrm{~m}(16 \mathrm{~km}$ northwest of Breda), FB zone (Doppert et al., 1979; Doppert, 1980) Oosterhout Fm, Holland. Pliocene; Coralline Crag and "Waltonian" Red Crag, East Anglia, England.

Description. Very large thick-shelled; sub-rectangular in lateral view compressed and oblong in dorsal view. Dimorphic. Male proportionally more elongate than female, though an overlap in size exists. Anterior margin broadly rounded with numerous, closely-spaced spinose denticles, extremity just below mid-height. Posterior margin bluntly rounded with 5 or 6 irregularly, widely spaced, sub-spatulate marginal denticles, extremity just above mid-height. Dorsal margin straight with well developed cardinal angles. Ventral margin straight but with slight median concavity. Greatest length at mid-height; greatest height at the anterior cardinal angle, greatest width medianly. LV $>$ RV. Ornament of sellate fossae, muri subdued marginally to form a series of linked fossae; elsewhere strong and of radial disposition about a pronounced sub-central tubercle which is minutely sellate. Anterior marginal rim with transverse, narrow, elongate fossae. Subalate ventrolaterally and terminates posterioventrally in a complex "loop". Two ribs enhance the dorsal margin. The most dorsal arises from a posterodorsal position, curves anteroventrally near mid-length and terminates below and behind eye tubercle; the other extends posteriorly from the eye tunercle to its termination at

Explanation of Plate 2

Figs 1-10. Aurila sherborni sp. nov.: fig. 1, Holotype MPK 9288 RV-M, ext. lat. (x60); fig. 2, Holotype MPK 9288, int. lat. (x60); fig. 3, Paratype MPK 9289 LV A-1, ext. lat. (x60); fig. 4, Paratype MPK 9290 RV-F, int. lat. (x59); fig. 5, Paratype MPK 9290, ext. lat. (x59); fig. 6, Paratype MPK 9295 Cp A-1, ext. ventral (x42); fig. 7, Paratype MPK 9295, ext dorsal (x42); fig. 8, Paratype MPK 9293 LV-F, int. lat. (x59); fig. 9, Paratype MPK 9296, ext. lat. (x59); fig. 10, Paratype MPK 9296 LV A-2, ext. lat. (x59).

Figs 11-15. Cletocythereis jonesi sp. nov.: fig. 11, Holotype OS 13949 Cp-M, ext. lat. LV (x48); fig. 12, Holotype OS 13949, ext. lat. RV (x48); fig. 13, Holotype OS 13949, ext. ventral (x45); fig. 14, Paratype MPK 9279 LV-F, ext. lat. (x52); fig. 15, Paratype MPK 9278, int. lat. (x32). 


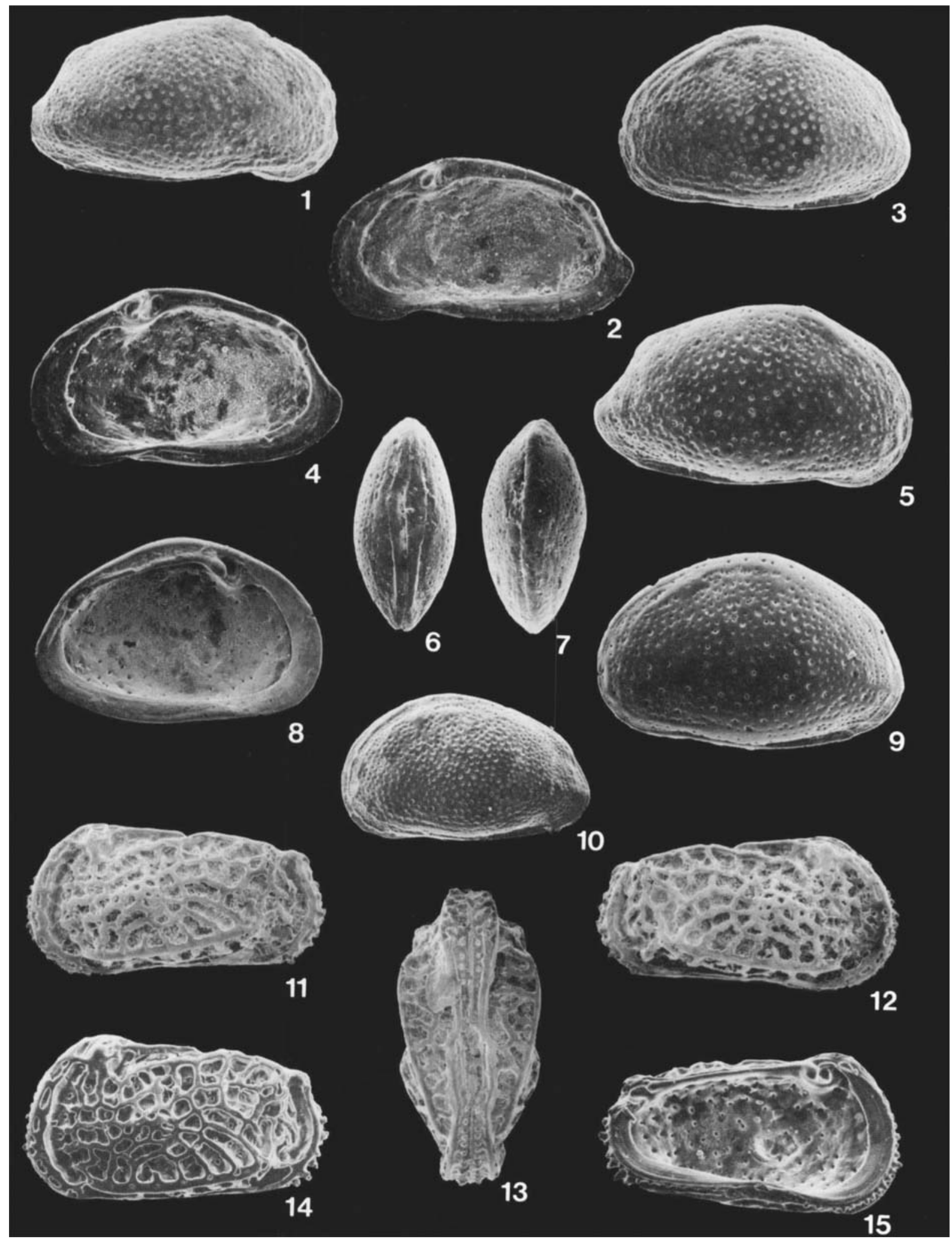


mid- length. Posterior marginal rim simple and narrow. Eye tubercle large and smooth. Sensillum pores of two types: sieve-type, large sellate and free standing; medium-sized conjunctive or intermural normal pores situated in low conuli. Inner lamella wide; anterior vestibule narrow; selvage strong with rounded profile, sub-peripheral. Marginal pore canals numerous, regularly spaced, thin and sinuous; anteriorly 2527, posteriorly 12 (fig. 7). Hinge modified holamphidont. In the LV, anterior to the anterior terminal socket, the selvage is expanded into a small rim-tooth. Median element smooth; posterior part is tooth-like and projects into the posteroterminal socket. Muscle scars lie in the deep depression of the subcentral tubercle and consist of four adductor scars, central two elongate; two frontal scars: the ventral component may be "bean-shaped" or "V", occasionally swollen; dorsal lobate. Three dorsal muscle scars situated mid-way between anterior muscle scars and hinge. Juveniles polygonally recticulate, subdued anteriorly, sunken with respect to the ventral alae. This ala is swollen posteriorly forming a " $\mathrm{U}$ " before returning postero-medianly towards the central tubercle. Hemiamphidont hinge developed in both the A-1 and A-2 stages.

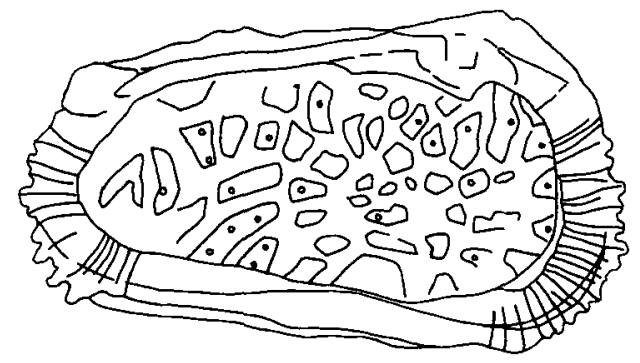

\section{B}

Fig. 7. Cletocythereis jonesi; ALV-F, paratype MPK 9278, OSC 1/ OR7a, as seen in transmitted light. Scale $B=100 u m$

\begin{tabular}{lccccc}
\multicolumn{6}{l}{ Dimensions (mm) (see fig. 8) } \\
\multicolumn{7}{c}{ Length } & Height & Nos & L:H ratio \\
Adults & Range & $1.15-0.98$ & $0.62-0.54$ & 20 & $1.84: 1$ \\
& Mean & 1.05 & 0.57 & & \\
A-1 & R. & $0.91-0.77$ & $0.49-0.43$ & 6 & $1.80: 1$ \\
& M. & 0.83 & 0.46 & & \\
A-2 & R. & $0.67-0.59$ & $0.43-0.33$ & 13 & $1.68: 1$ \\
& M. & 0.62 & 0.37 & & \\
A-3 & M. & 0.48 & 0.30 & 1 & $1.61: 1$
\end{tabular}

Remarks. Cletocythereis jonesi sp. nov. displays a number of similarities, in the disposition of recticulation and in the general outline of the carapace, to the lower Oligocene species
Cletocythereis memorans (Moos, 1965) from northwest Germany, which is a possible ancestor of the present species. Jones \& Sherborn (1887 \& 1889) mistakenly considered the juveniles of $C$. jonesi to be synonymous with Cythereis hoernesi (Speyer,1863), a smaller and less alate species, also from the Oligocene of Germany. The new species differs from $C$. rastromarginata Brady, the type species in the subrectangular outline of the carapace in lateral view; the broadly rounded posterior, traversely arranged fossae on the anterior marginal rim and in the number and disposition of marginal denticles.

\section{ACKNOWLEDGEMENTS}

The authors extend their thanks to Leendert Witte of the Netherlands Geological Survey, Brian Funnel and Christopher Hunt for providing material for this study. Special thanks to John Whittaker of the British Museum (Natural History) for access to T.R. Jones type material and to Mr D. Griffiths and Mr G. Hughes for their help with photography.

Manuscript received July 1992

Manuscript accepted September 1992

\section{REFERENCES}

Andrew, R. \& West, R. 1977. Pollen spectra from the Pliocene Crag at Orford, Suffolk. New Phytol, London, Cambridge, 78, 709-714.

Athersuch, J. 1982. Some ostracod genera formerly of the Family Cytherideidae Sars. In Bate, R.H., Robinson, G., \& Sheppard, L.M. (Eds), Fossil and Recent Ostracods, 231-275, pls 1-8, t.figs 1-8. Ellis Horwood Ltd., Chichester for British Micropalaeontological Society.

Balson, P. 1981. The sedimentology and palaeoecology of the Co ralline Crag (Pliocene) Suffolk. Unpub. Ph.D. thesis, University of London, 364 pp.

Balson, P. 1990. The Neogene of East Anglia - a field excursion report. Tert. Res. London, 11(2-4), 179-189.

Bosquet, J. 1852. Description des Entomostraces fossilie des terrains tertaires de la France et de la Belgique. Mem. Acad.r.Lett.Belq., Bruxelles, 24, 142 pp., 6 pls.

Charlesworth, E. 1835. Observations on the Crag Formation andi $t s$ organic remains: with a view to establishing a division of the Tertiary strata overlying the London Clay in Suffolk. Lond. Edinb. Dubl. Phil. Mag. series 3, 7, 81-94.

Doppert, J., Laga, P. \& Meuter, F. de, 1979. Correlation of the biostratigraphy of marine Neogene deposits, based on benthonic foraminifera, established in Belgium and the Netherlands. Meded. Rijks geol. Dienst, Leiden, 31(1), 1-8.

Doppert, J. 1980. Lithostratigraphy and biostratigraghy of marine Neogene deposits in the Netherlands. Meded. Rijks geol. Dienst, Leiden, 32(16), 255-311.

Jones, T.1857. A monograph of the Tertiary Entomostraca of England. Palaeontogr. Soc. (Monogr.), London, 9, 68pp, 6pls.

Explanation of Plate 3

Figs 1-12. Cletocythereis jonesi sp. nov.: fig. 1, Paratype MPk 9231 LV-M, ext. lat. inclined dorsally (x48); fig. 2, Paratype MPk 9280 RV-M, ext. lat. inclined dorsally (x47); fig. 3a Paratype MPK 9280 int. lat. (x48); fig. 3b, Paratype MPK 9280, detail of hinge (x86); fig. 3c, Paratype MPK 9280, detail central muscle scars (x270); fig. 4a Paratype MPk 9281 LV-M, int. lat. (x48); fig.4b, Paratype MPK 9281, detail of hinge (x90); fig. 4c, Paratype MPK 9278, detail central muscle scars (x270); fig. 5, Paratype MPK 9281, ext. lat. (x48); fig. 6, Paratype MPK 9280, ext. lat. (x48); fig. 7, Paratype MPK 9285 LV A-1, ext. lat. (x50); fig. 8; Paratype MPK 9283 RV A-1, int. lat. (x50); fig. 9, Paratype MPK 9285, int. lat. (x50); fig. 10, Paratype MPK 9283, ext. lat. (x50); fig. 11, Paratype MPK 9284 LV A-2, ext. lat. (x50); fig. 12, Paratype MPK 9286 RV A-2, ext. lat. (x50). 


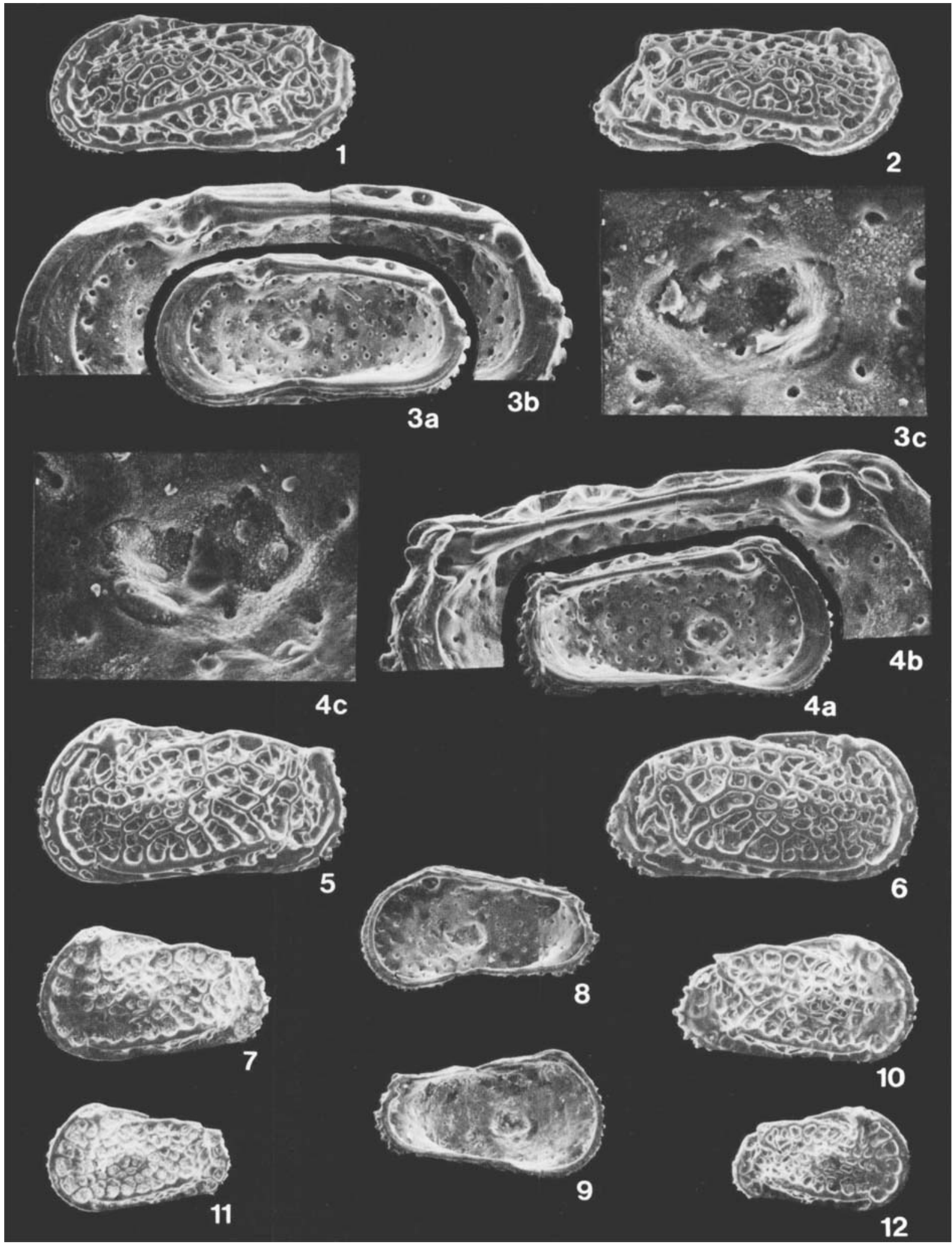




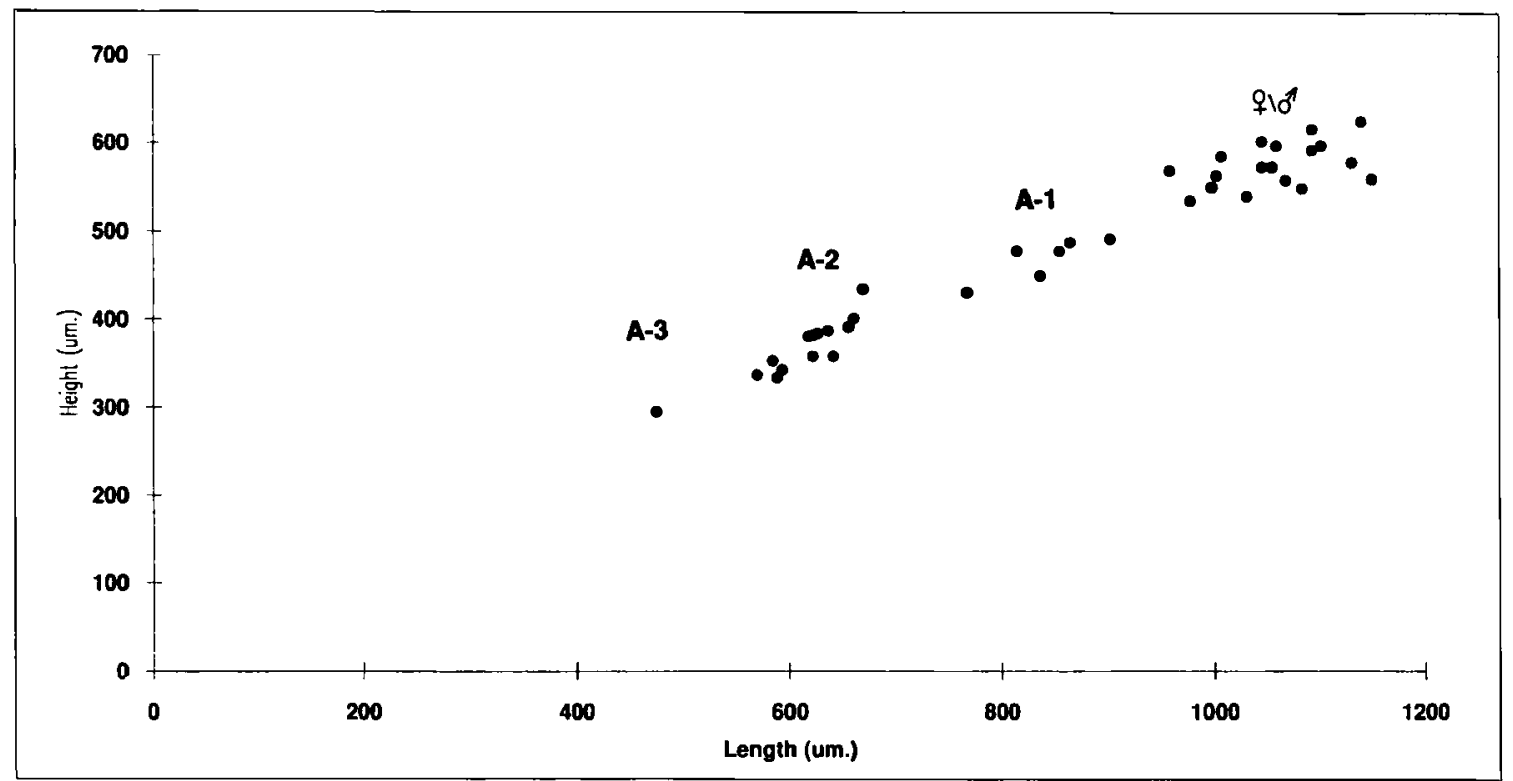

Fig. 8. Size distribution of adults and juveniles of Cletocythereis jonesi sp. nov.

Jones, T. 1870. Notes on the Tertiary Entomostraca of England. Geol. Mag., London, 7, 155-159

Jones, T. \& Sherborn, C.,1887. Further notes on the Tertiary Entomostraca of England with special reference to those from the London Clay. Geol. Mag., London, 3(4-9), 385-393, 450-460, pl.1.

Jones, T. \& Sherborn, C. 1889. A supplementary monograph on the Tertiary Entomostraca of England. Palaeontogr. Soc. (Monogr.), London, 69, 55pp. 3pls.

McKenzie, K. 1967. Recent Ostracoda from the Port Phillip Bay, Victoria. Proc. R. Soc. Vict., Melbourne, 80(1), 61-106.

Malz, H. 1980. Cletocythereis Swain 1963 (Ostracoda); besondere Merkmale und geographische Vertreitung ihrer Arten. Seckenberg. leth., Frankfurt a.M., 60(4-6), 381-397.

Maybury, C., 1985. Taxonomy, palaeoecologyand biostratigraphyof Pliocene benthonic Ostracoda from St.Erth and N.W. France. Unpub. Ph.D. thesis, University of Wales, 705pp., 49pls.

Moos, B. von 1965. Die Ostracoden-Fauna des Unteroligozans von Bunde (BL. Herford-West, 3817) und einige verwandte jungere arten (Ostr., Crust.). Geol. Jb., Hannover, 82, 593-630, 6pls.

Speyer, O. 1863. Die Ostracoden aus den Kasseler Tertiarbilungen. Ber. Ver. Naturk. Cassel, 63pp., 4pls.

Wilkinson, I. 1974. Ostracoda of the Coralline Crag, Suffolk. Unpub. M.Sc. thesis, University of Wales, $112 \mathrm{pp}, 11 \mathrm{pls}$.

Wilkinson, I., 1980. Coralline Crag Ostracoda and their enviromental and stratigraphical significance. Proc. Geol. Ass., London, 91, 291306.

Wouters, K. 1973. Le genre Aurila Pokorny (Crust., Ostr.) dans le PlioPliestocene de Belgique. Revue. de Micropaleont., Paris, 16(4), 194201

Wouters, K., 1978. Een systematische, biostratigrfische en paleobiolgische studievon de Ostracoda uit Mioceneabzettingen in noorde-Belgie. Unpub. Ph.D.thesis, University of Leuven, 338 pp., 48pls. 